Gut, 1981, 22, 534-541

\title{
Ultrastructure of endocrine-like cells in lamina propria of human gastric mucosa*
}

\author{
J STACHURA, W J KRAUSE, AND K J IVEY† \\ From the Veterans Administration Medical Center, Long Beach, California; University of California Irvine, \\ Irvine, California; Department of Anatomy, University of Missouri School of Medicine, Columbia, \\ Missouri; and the Institute of Pathology, Copernicus Medical Academy, Krakow, Poland
}

SUMMARY Endocrine cells of gastric and gut mucosa are commonly thought to be present only within mucosal glands. In a previous report, we described argyrophilic cells in the lamina propria in $40 \%$ of surgical gastric specimens, using light microscopy. All these patients had chronic gastritis. Argyrophilia, however, is a non-specific reaction which could occur in other than endocrine cells. The present study was undertaken to describe the ultrastructure of argyrophil cells in the lamina propria. In five patients with chronic gastritis, endoscopic biopsies were taken from the fundic, intermediate, and pyloric areas of the stomach. Single and/or clustered argyophil cells were seen by light microscopy in the lamina propria of the intermediate and pyloric areas. On electronmicroscopy, these cells had the following characteristics of endocrine-like cells: they were characterised by numerous electron dense granules in the cytoplasm, 100-300 nm in diameter; the cytoplasm contained poorly-developed rough endoplasmic reticulum and well-developed smooth endoplasmic reticulum with occasional vesicles. Immunostaining gave negative results for various gastrointestinal hormones. These ultrastructural characteristics of lamina propria cells are similar to endocrine cells of the APUD series. We conclude that endocrine-like cells occur in the lamina propria of the human stomach in the presence of chronic gastritis.

Endocrine cells of gastrointestinal mucosa are usually found within mucosal glands. ${ }^{1}$ Light microscopic examination has suggested the presence of endocrine cells in the lamina propria of intermediate and pyloric mucosa of pathological human gastric mucosa. ${ }^{2}$ Argyrophilic cells, singly or in groups, were found in the lamina propria of 22 of 56 surgical gastric specimens of patients operated on for gastric or duodenal ulcer or gastric cancer. All subjects with argyrophilic cells in the lamina propria had chronic gastritis. ${ }^{2}$ The argyrophilic reaction, however, is non-specific, and thus it could only be hypothesised that these argyrophilic cells were endocrine cells. $^{2}$ This study presents ultrastructural evidence for endocrine-like morphological characteristics of these argyrophilic cells in the gastric lamina propria of man.

*This work was supported in part by the CRC NIH Grant No. RR 00287-12 and Biomedical Grant No. RR 07053, and by the Medical Research Service of the Veterans Administration.

†Address for all correspondence and reprint requests: Dr K J Ivey, Gastroenterology Section (111G), Veterans Administration Medical Center, 5901 East Seventh Street, Long Beach, California 90822, USA.

Received for publication 9 January 1981

\section{Methods}

Biopsies of five subjects (four female, one male, aged 25-47 years) were investigated by light and electron microscopy. Biopsies were chosen from 60 patients endoscoped during a three-month period for investigation of gastric or duodenal ulcer disease or dyspepsia. A duplicate biopsy was taken from pyloric (about $2 \mathrm{~cm}$ from pylorus), intermediate $(7-9 \mathrm{~cm}$ from pylorus along greater curvature), and body (mid-greater curvature) areas in each patient. One biopsy was routinely examined histologically, the other was collected in Epon blocks. Biopsies from five of these 60 subjects showing argyrophil positive lamina proprial cells in the pyloric and/or intermediate area were chosen for ultrastructural investigations.

Tissue for histological examination was fixed in $10 \%$ neutral formalin and embedded in paraffin. Paraffin sections were stained with haematoxylin and eosin (H and E). Periodic acid-Schiff (PAS) reaction, with Grimelius method for argyrophilia, ${ }^{3}$ and the Masson-Fontana ${ }^{4}$ angentaffin reaction 
Table Immunohistochemical investigations of endocrine-like cells in lamina propria by $P A P$ methods ${ }^{5}$

\begin{tabular}{|c|c|c|}
\hline Antiserum to & $\begin{array}{l}\text { Dilution } \\
\text { used }\end{array}$ & Source \\
\hline Gastrin I and II & $1: 500$ & Calbiochem \\
\hline Glucagon & $1: 1000$ & Calbiochem \\
\hline Somatostatin & $1: 300$ & $\begin{array}{l}\text { A Arimura, Tulane Univ. } \\
\text { School of Med, New Orleans, } \\
\text { Louisiana, USA }\end{array}$ \\
\hline VIP & $1: 2500$ & $\begin{array}{l}\text { S I Said, Depts of Internal } \\
\text { Med. and Pharmacol., Univ. } \\
\text { Texas, Dallas, USA }\end{array}$ \\
\hline Secretin & $1: 500$ & Calbiochem \\
\hline $\begin{array}{l}\text { Pancreatic polypeptide } \\
\text { (bovine) }\end{array}$ & $1: 500$ & $\begin{array}{l}\text { Lilly Res Labs, Indianapolis, } \\
\text { Indiana, USA }\end{array}$ \\
\hline Substance $P$ & $1: 500$ & $\begin{array}{l}\text { R H Ho, Dept of Anatomy, } \\
\text { Ohio State Univ, Columbus, } \\
\text { USA }\end{array}$ \\
\hline
\end{tabular}

were performed.

Tissue for ultrastructural examination was fixed in $2 \%$ glutaraldehyde in phosphate buffer, $\mathrm{pH} 7.4$ at $4^{\circ} \mathrm{C}$ for two hours. Tissues were then washed in phosphate buffer, $\mathrm{pH} 7 \cdot 4$, and postfixed in $2 \%$ osmium tetroxide for two hours, dehydrated in a graded series of ethyl alcohol, and embedded in Epon 812 resin. Silver-grey thin sections were stained with uranyl acetate and lead citrate and examined on a Philips 300 electron microscope operated at $80 \mathrm{KV}$.

Immunostaining for gut hormones was performed according to Sternberger's PAP method ${ }^{5}$ using formalin-fixed paraffin sections. Antisera used, dilution and source are shown in the Table.

\section{Results}

L I G H T M I C R O S C O P Y

Chronic gastritis was present in the biopsies of the pyloric and intermediate areas in all five subjects showing argyrophil positive lamina proprial cells. Focal intestinal metaplasia was present in two of these subjects. Focal superficial gastritis occurred in the fundic area.

Based on the Grimelius argyrophil reaction, we found numerous positive staining endocrine cells in the gastric pyloric and fundic glands as has been well described by others. In addition, single and/or groups of argyrophil cells were found in the lamina propria as well, in the pyloric and intermediate zones (Fig. 1). The position of these cells in the lamina propria of the mucosa is shown in Fig. 2. The Masson-Fontana argentaffin reaction was negative.

ELE C T R O N M I C R O S COP Y

Ultrastructural examination showed these argyrophil cells in the lamina propria to be endocrine-

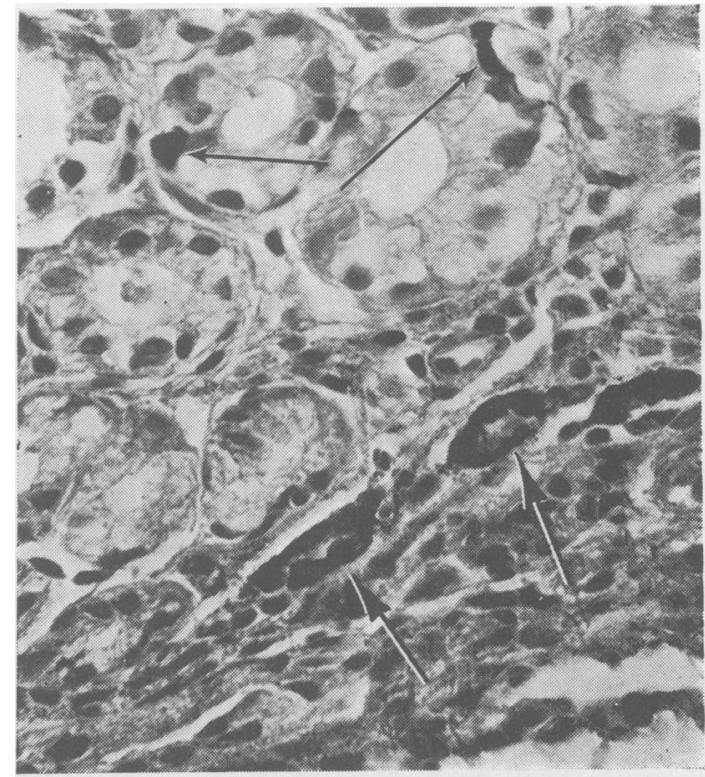

Fig. 1 Groups of argyrophil cells (large arrow) localised in the lamina propria. Single argyrophil cells also are observed within glandular epithelium (small arrow). $\times 260$.

like cells (Figs 3 and 4). They were characterised by round and oval electron dense granules 100$200 \mathrm{~nm}$ in diameter in some cells (type I, Fig. 5) and $150-300 \mathrm{~nm}$ in other cells (type II, Fig. 6). The nuclei of these cells were oval and slightly irregular in shape, with well-developed, smooth endoplasmic reticulum, with occasional vacuole formation. Mitochondria were not very numerous. Lysosomal bodies containing electron dense material were also noticed. Cell boundaries usually were poorly defined, as they were intermingled with collagen fibres. Occasionally, the endocrine-like cells formed small clusters of two to five cells (Figs 7 and 8). Some cells were found close to the basal lamina of the gastric glands; others, however, were situated deep in the connective tissue of the lamina propria, far away from the glandular cells. We observed nerve fibres close to some endocrine-like cells. Other endocrine-like cells were situated adjacent to small blood vessels (Fig. 8).

A moderate inflammatory infiltrate with numerous plasma cells was observed within the lamina propria, as were granulated mast cells. Parietal and mucous cells present in the gastric glands were morphologically normal. Endocrine cells in the normal distribution within gastric glands were primarily enterochromaffin-like 


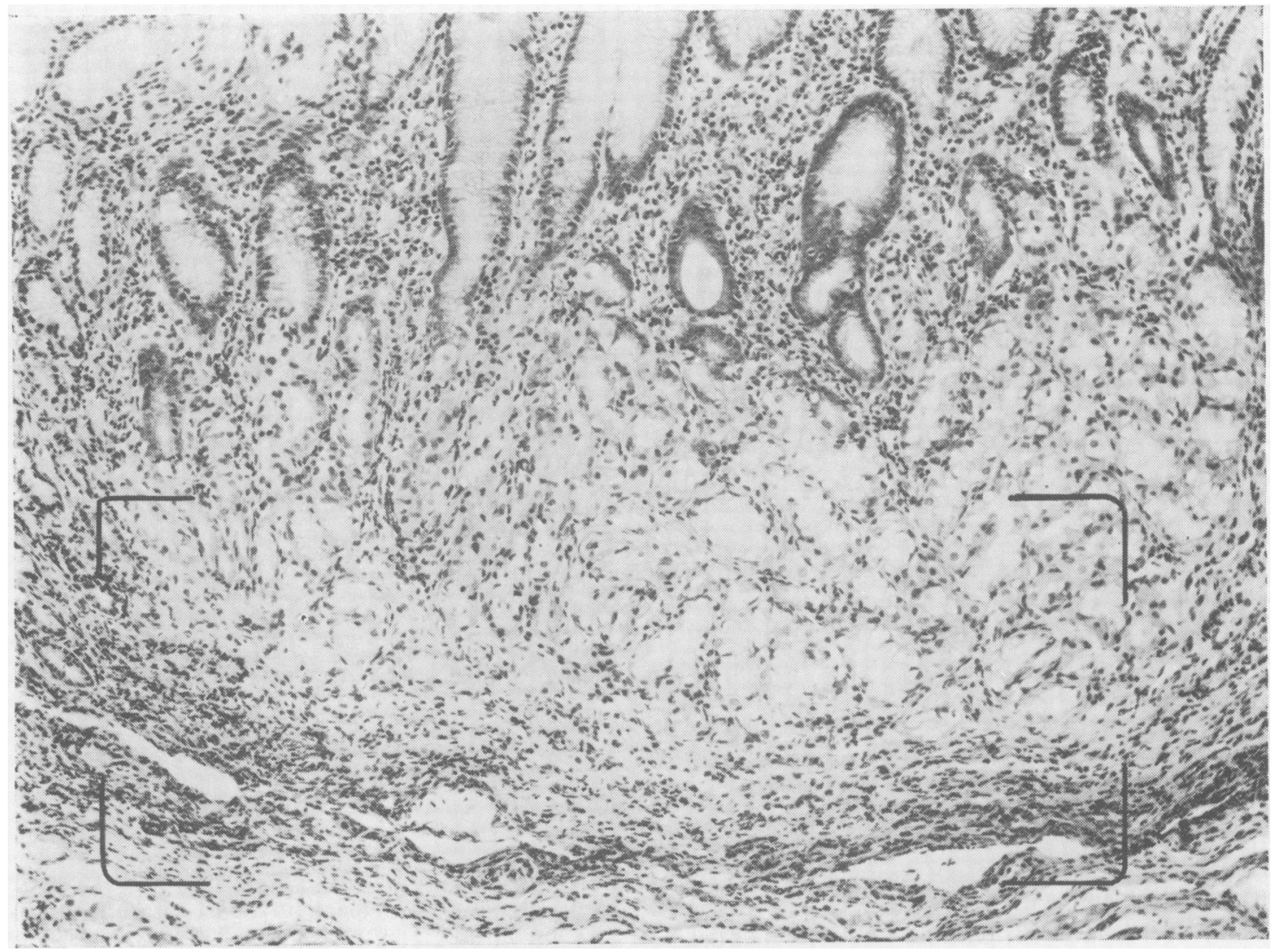

Fig. 2 Histological picture of the pyloric mucosa with bracketed area occupied by lamina proprial argyrophil cells. $H$ and $E, \times 100$.

cells, enterochromaffin cells, and $D_{1}$ cells (classified according to Lausanne 1977 classification $^{1}$ ). The endocrine-like cells found in the lamina propria did not resemble any of the endocrine cells normally found in the stomach. Some of the cells studied (type $I$ ) were similar to $D_{1}$ cells by the size of granules. Immunostaining for VIP was negative, however, in our formalin-fixed, paraffin-embedded material.

I M M U N O S T A I N I N G

Immunohistochemical reactions for gastrin, glucagon, somatostatin, pancreatic polypeptide, secretin, substance $P$, and VIP were negative.

\section{Discussion}

While it is generally believed that endocrine cells in the gastrointestinal tract are scattered between epithelial glandular cells of the mucosa, recent studies have suggested that similar cells may be found in the lamina propria.$^{6-10}$

Ultrastructural investigations of rat gastric lamina propria have demonstrated directly innervated, granulated, endocrine-like cells. ${ }^{6-810}$ Granulated cells in the duodenal lamina propria of the human fetus were also reported. ${ }^{9}$ In these studies, granulated cells were closely connected with unmyelinated nerve fibres. The authors postulated that these 'neuroendocrine' cells may have a possible neuroendocrine function. To our knowledge, there has been no published ultrastructural study of endocrine-like cells in human adult gastric lamina propria.

Our present study clearly shows the similarity of granulated cells of lamina propria to other polypeptide hormone-producing cells of the APUD series. ${ }^{11} 12$ In our five patients we were unable to demonstrate a neuroendocrine complex, as reported by Japanese workers; ${ }^{6-10}$ in our study, however, nerve endings close to the endocrine-like cells were observed. Our findings 


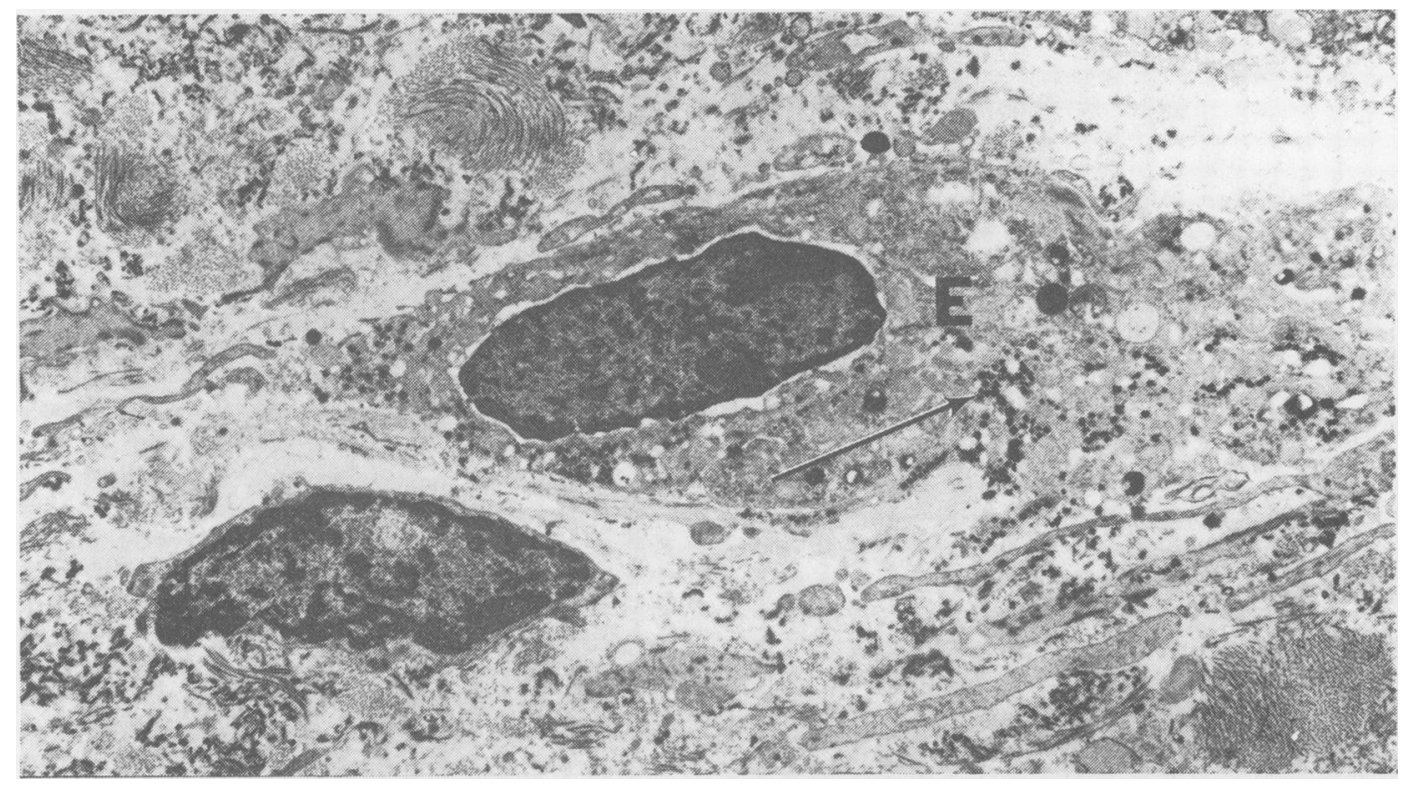

Fig. 3 Endocrine-like cell $(E)$ situated in the connective tissue of lamina propria. Note the secretory granules (arrow). $\times 7000$.

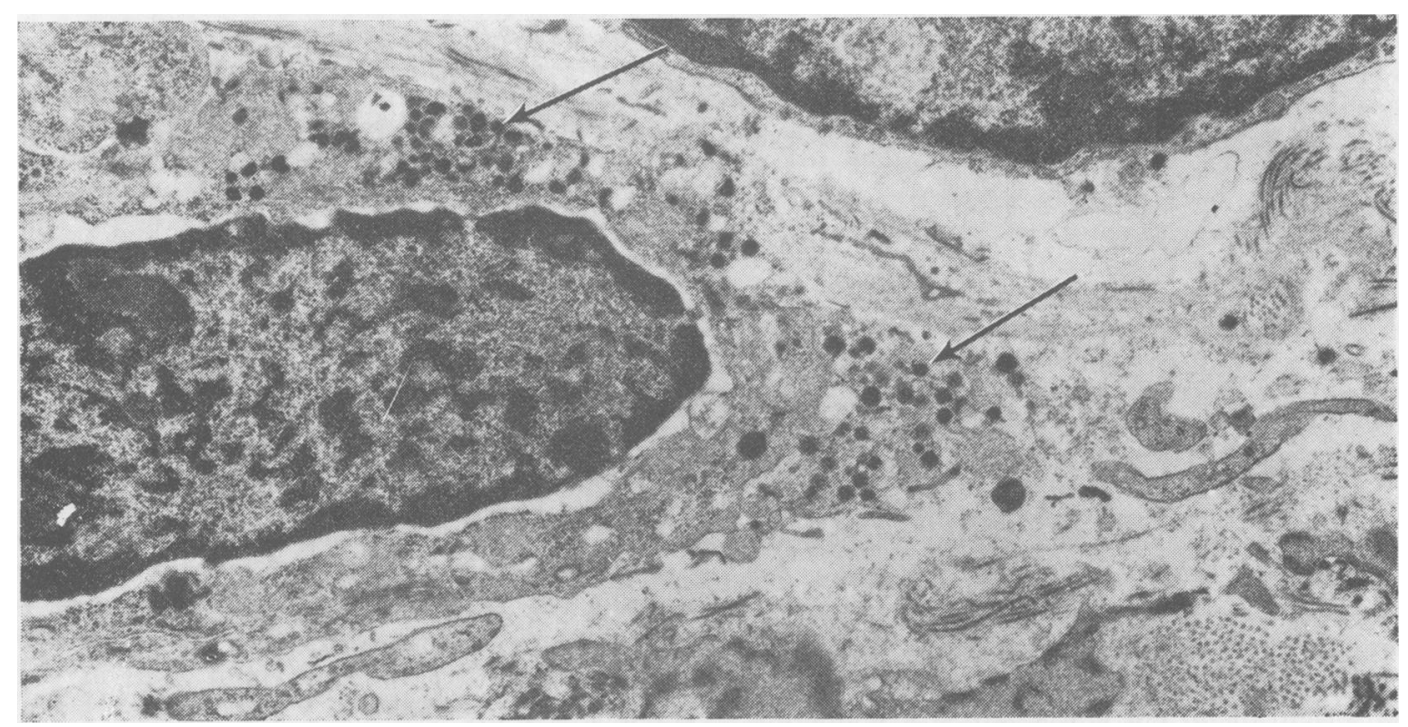

Fig. 4 Increased magnification of the cell shown in Fig. 3. Note the irregular distribution and variation in size of secretory granules (arrows). A fibroblast nucleus is seen at the upper right. $\times 10000$. 


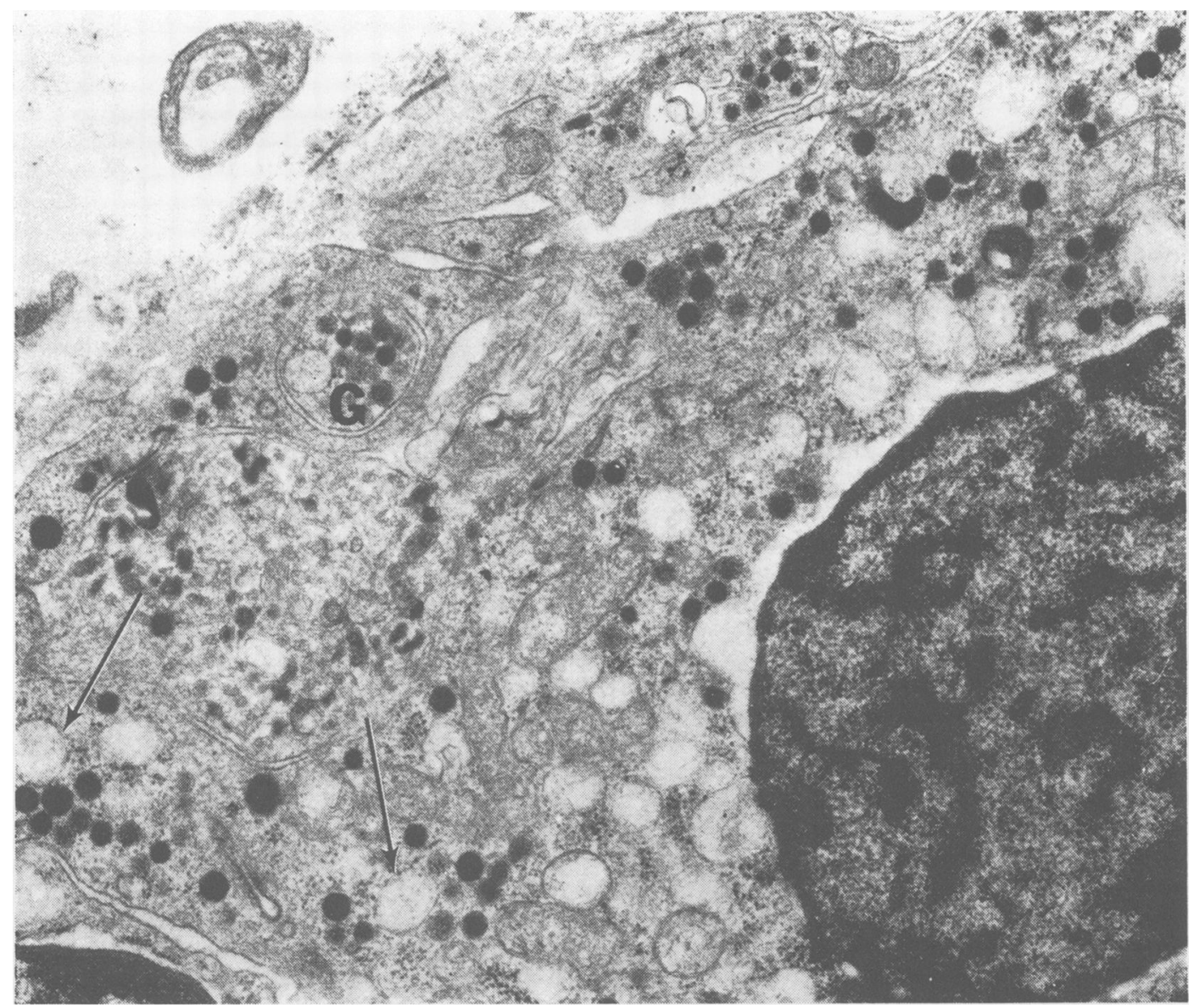

Fig. 5 Details of the endocrine-like cell (type I). Note secretory granules $(G)$ of 100-200 nm in diameter and endoplasmic reticulum (arrows). $\times 17500$.

were also different from those of Solcia who described a nodular hyperplasia of pyloric endocrine cells closely applied to pyloric glands. ${ }^{13}$

The close relationship between neural and endocrine tissues has been widely recognised and led Pearse 1112 to hypothesise the origin of the APUD series in neurally programmed ectodermal cells. This hypothesis is supported by common peptides found in both neural tissue and in gut endocrine cells. 14-19 An alternative viewpoint to this hypothesis is that there is a common endodermal origin of all gut epithelial cells, including endocrine cells. ${ }^{20-22}$ From our study, we are unable to provide any evidence as to the origin of these endocrine-like cells. The function of lamina proprial endocrine-like cells remains unknown. Our efforts to identify some of the known gut hormones by immunohistochemistry were negative.

Endocrine-like cells in the lamina propria could be due to migration of endocrine cells from within the mucosal glands. Or, these cells may have been present in the lamina propria de novo and have been stimulated to proliferate in pathological conditions such as chronic gastritis. By analogy, carcinoids are considered to develop from gut endocrine cells. These tumours, however, typically are found in the lamina propria or the submucosa of the gut (and not in the glandular epithelium). ${ }^{42324}$ At some stage, therefore, endocrine cells which can proliferate into carcinoid tumours must be present in the lamina propria. Our present study provides evidence that endocrine-like cells can occur in the lamina propria, at least in pathological conditions of the stomach such as chronic gastritis. 
Fig. 7 A group of endocrine-like cells in the lamina propria. Note poorly defined cell boundaries. $A$ vertical score mark is noticeable. $\times 7500$. 


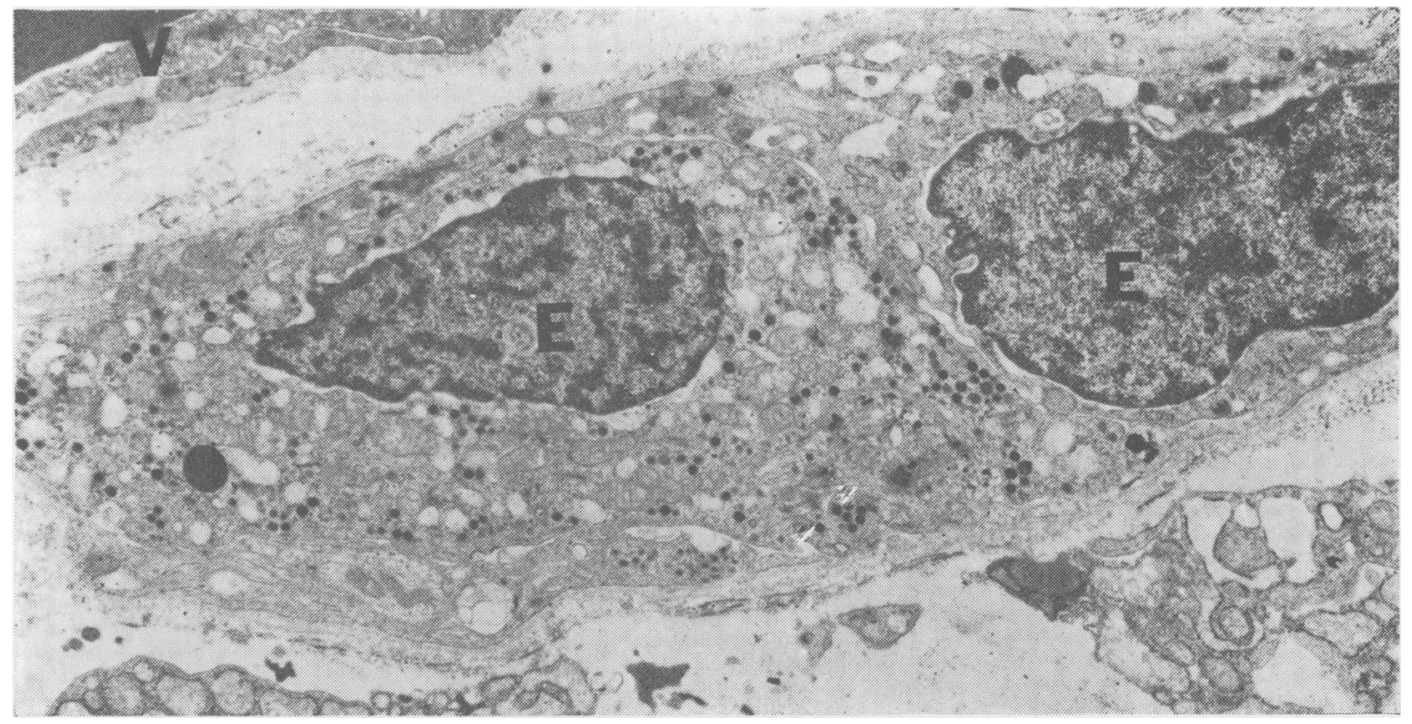

Fig. 8 Two endocrine-like cells $(E)$ situated in the lamina propria close to the blood vessel $(V) . \times 8000$.

\section{References}

1Solcia E, Polak JM, Pearse AGE, et al. Classification of gastroentero-pancreatic endocrine cells. In: Bloom SR, ed. Gut hormones. Edinburgh: Churchill Livingstone, 1978: 40-8.

${ }^{2}$ Stachura J, Urban A, Bigaj M, et al. Histochemical and ultrastructural observation of endocrine cells in pathological gastric mucosa. Folia Histochem Cytochem (Krakow) 1978; 16:287-98.

${ }^{3}$ Grimelius L. A silver nitrate stain for $a_{2}$ cells in human pancreatic islets. Acta Soc Med Upsal 1968; 73:243-70.

4 Masson P. Carcinoids (argentaffin-cell tumours) and nerve hyperplasia of the appendicular mucosa. $A m$ J Pathol 1928; 4:181-211.

5Sternberger LA. Immunocytochemistry. Englewood Cliffs NJ: Prentice-Hall. 1974.

${ }^{6}$ Fujita T, Kobayashi S. Structure and function of gut endocrine cells. Int Rev Cytol 1977; suppl 6: 187-233.

'Matsuo Y, Seki A. The coordination of gastrointestinal hormones and the autonomic nerves. $A m$ J Gastroenterol 1978; 69:21-50.

${ }^{8}$ Matsuo Y, Seki A, Fekuda S. Neuroendocrine cells in the lamina propria of rat stomach. In: Fujita $T$, ed. Endocrine gut and pancreas. Amsterdam: Elsevier, 1976: 159-65.

'Osaka M, Kobayashi S. Duodenal basal-granulated cells in the human foetus, with special reference to their relationship to nervous elements. In: Fujita T, ed. Endocrine gut and pancreas. Amsterdam: Elsevier, 1976: 133-44.

${ }^{10}$ Matsuo Y, Seki A. Integration of hormonal and neural control of gastro-intestinal secretion. A sian Med J 1976; 19:15-56.
${ }_{11}$ Pearse AGE, Polak JM. The diffuse neuroendocrine system and the APUD concept. In: Bloom SR, ed. Gut hormones. Edinburgh: Churchill Livingstone, 1978: 33-9.

12Pearse AGE, Takor T. Embryology of the diffuse neuroendocrine system and its relationship to the common peptides. Fed Proc 1979; 38:2288-94.

${ }^{13}$ Solcia E, Capella C, Varsalle G, et al. Endocrine cells of the gastric mucosa. Int Rev Cytol 1975; 42:223-86.

${ }^{14}$ Larsson LI. Gastrointestinal cells producing endocrine, neurocrine and paracrine messengers. Clin Gastroenterol 1980; 9:485-516.

${ }_{15}^{15}$ undler F, Hakanson R, Leander S. Peptidergic nervous system in the gut. Clin Gastroenterol 1980; 9:517-44.

${ }^{16}$ Zimmermann EG. Peptides in the brain and gut: Introductory remarks. Fed Proc 1979; 38:2286-7.

${ }^{1}$ iSundler F, Alumets J, Hakanson R. Peptides in the gut with the dual distribution in nerves and endocrine cells. In: Bloom SR, ed. Gut hormones. Edinburgh: Churchill Livingstone, 1978: 406-13.

${ }^{18}$ Fuxe K, Andersson K, Hokfelt T, et al. Localisation and possible function of peptidergic neurons and their interactions with the central catecholamine neurons, and the central actions of gut hormones. Fed Proc 1979; 38:2333-2340.

${ }^{19}$ Strause E, Yalow RS. Gastrointestinal peptides in the brain. Fed Proc 1979; 38:2320-4.

${ }^{20}$ Cheng $\mathrm{H}$, Leblond CP. Origin, differentiation and renewal of the four main epithelial cells types in the mouse small intestine. V. Unitarian theory of the origin of the four epithelial cell types. Am J Anat 1974; 141:537-62.

21Pictet RL, Rall LB, Phelps P, et al. The neural crest and the origin of the insulin-producing and 
other gastrointestinal hormone-producing cells. Science 1976; 191:191-2.

${ }^{22}$ Le Douarin NM. The embryological origin of the endocrine cells associated with the digestive tract: Experimental analysis based on the use of a stable cell marking technique. In: Bloom SR, ed. Gut hormones. Edinburgh: Churchill Livingstone, 1978: 49-56.
${ }^{23}$ Tischler AS, Dichter MA, Biales B, et al. Neuroendocrine neoplasms and their cells of origin. N Engl J Med 1977; 296:919-25.

${ }^{24}$ Soga J. Neoplasm of GEP endocrine cells: the present day concept of carcinoids. In: Fujita T, ed. Endocrine gut and pancreas. Amsterdam: Elsevier, 1976: 387-94. 